\title{
The Effect of Certification and Work Motivation on Teacher Performance in the Teacher Working Group of Lempuing District Ogan Komering Ilir
}

\author{
Miftahu rahman ${ }^{1 *}$, Happy Fitria ${ }^{2}$, Achmad Wahidy $^{2}$ \\ ${ }^{l}$ KKG Lempuing District Ogan Komering Ilir \\ ${ }^{2}$ Universitas PGRI Palembang \\ rahmanmiftahu@yahoo.com,happyfitria2006@gmail.com,achmadwahidy@gmail.com
}

\begin{abstract}
The research aims to find out the effect of certification, and work motivation on teacher performance in the Teacher Working Group (KKG) of Lempuing sub-district Ogan Komering Ilir partially and simultaneously. Research hypothesis (1) certification affects teacher performance, (2) work motivation affects teacher performance, (3) certification and work motivation jointly affect teacher performance. This research method is quantitatively correlational, with the research population of all certified teachers in kkg Lempuing subdistrict amounting to 65 teachers. Data is collected with documentation and questionnaires. Analyzed using descriptive statistics, and hypotheses analyzed using simple regression equations and multiple regressions with the help of SPSS. 24. The results showed that: (1) there is a significant influence of certification on teacher performance, (2) there is a significant effect of work motivation on teacher performance, and (3) there is a significant effect of teacher certification and motivation on teacher performance in KKG Lempuing district Ogan Komering Ilir.
\end{abstract}

Keywords: Certification, Work Motivation and Teacher Performance

\section{INTRODUCTION}

Teachers are human resources that play a role in creating and succeeding educational activities as one of the education personnel is expected to be able to print intelligent, dignified and quality and useful students. Various government efforts in the field of education are to improve the ability of teachers to carry out their obligations properly. The role of teachers is the determinant of the success of the mission of education and learning in schools, teachers are responsible for organizing, directing, and creating a conducive atmosphere that encourages students to carry out the learning process. Teachers have an important role in education and even other educational resources, in other words teachers are the spearhead in efforts to improve the quality of services and educational outcomes.[1]
Therefore, teachers must have academic qualifications, competencies, certificates of educators, physical and spiritual health and the ability to realize national education goals as stated in [2]. This is also confirmed in article 8 of [3] states that it is mandatory for every teacher to have academic qualifications, competencies, certification of educators, physical and spiritual health, and have the ability to realize national educational goals. The scope of national standards of education includes standards of content, processes, competencies of graduates, educators and education personnel, facilities and infrastructure, management, financing and assessment of education.[4]

To create superior human resources only with education, the school becomes an institution of choice in the ministry of education. To develop and implement the vision, mission, and objectives and functions of the school, the school needs teachers as professionals, as well as schools are in desperate 
need of other resources such as financial and nonfinancial coverage that support the implementation of the goals of a school institution. In education units such as teacher performance schools become a very important support in the achievement of a school goal.[5] Since the passing of on Teachers and Lecturers in the World of Education Indonesia has undergone significant reforms. This law has the impact of expectations in improving the welfare and professionalism of teachers, because it mandates that education funds be allocated $20 \%$ of the State Budget.

The Teachers Working Group (KKG) as a place of teacher work in public elementary schools, seeks in a week-long scheduled one-week meeting to discuss teacher work activities to maximize teacher work to provide the best for students in their respective schools.

The results of observations made in the KKG District Lempuing Ogan Komering Ilir district is known that there are some problems about teacher certification whose performance is still not maximal, for example there are still found there are some teachers who come in less timely certification to school, there are still certification teachers who have not routinely made the administration of learning planning, this is because it is more due to lack of awareness and sense of responsibility as teachers who have been certified as motivation for their work. The motivation of the teacher's work certification has not been optimal because of the teacher's low performance. The main task of professional educator teachers with the main task of educating, teaching, guiding, directing, training and assessing and evaluating learners is also still low. Thus it is hoped that through the teacher certification program will be able to improve the performance of the teacher itself.

Based on the description above, the researchers wanted to know if there is an impact of teacher certification and teacher motivation in improving teacher performance in schools, so that research will be conducted on "The Effect of Certification and Work Motivation on Teacher Performance in KKG Lempuing District Ogan Komering Ilir".

Etymologically performance derived from the word 'work achievement' or in the popular language performance translated into Indonesian is often different, until now it has not been standardized. Performance there is interpreted as a show of work, work, work, implementation of work and the results of the implementation of work. Performance is the embodiment of the work done by employees that is commonly used as the basis of assessment of employees in the organization. This opinion refers to the work or work.[6] Specifically defined the teacher's performance as a set of real behaviors that the teacher showed at the time, he was giving learning to students. Notoatmojo defines performance as a visible result, where performance can be measured by work, tasks and activities over a period of time.[7] Performance is an activity carried out to be carried out the completion of duties and responsibilities in accordance with the expectations and objectives that have been determined.[8] Therefore, the understanding of teacher performance can be concluded as a condition that shows the ability of teachers in carrying out their duties in school and the creation of actions shown by teachers during learning activities that include arranging learning planning, conducting assessments, conducting feedback, and preparing remedial programs. Teacher performance can also be shown from how much competency is required to be fulfilled.

In today's globalization era quality is the main thing demanded in every service. So is education. Good teacher quality is a demand that cannot be put on hold and ignored. Certification is a program process to produce qualified teachers and competencies in order to carry out their duties properly and professionally.

Certification is defined as the process of granting educator certificates for teachers and lecturers as recognition given to teachers and lecturers as professionals formally, Professionalism is a form or field of activity that can provide services with high specialization and intellectuality[9] Meanwhile, according to teacher certification is improving the quality of teacher work to answer the current globalization of post-certification performance,[10] addressing the decentralization system and having a big effect on certified teachers. This means that after the process of granting certificates of educators to teachers who have met the requirements and are able to achieve national education goals along with improving the quality of work and the feasibility of teacher welfare.

In line with the government program in Article 42 of [11] that the requirement of educators must have a minimum education qualification strata one and authorized to teach in accordance with the qualifications of certification, able-bodied physical 
and spiritual, and capable and able to create educational goals. In Article 28 [12] is made clear about the National Standards of Education, and in [13] Article 8 teachers must have a minimum education of D4/S1 and are required to be able to provide learning in accordance with their fields.

According to [11] the foundation of teacher certification is: Legal, Psychological, Sociological, and Economic Foundation. The legal basis quoted in is, Law [10] (National Education System), [5] (Teachers and Lecturers), PP RI No. [4] (National Standards of Education), PP RI No. [2] (Teacher), [3] (Standards of Qualifications and Competencies of Educators), Decree of the Ministry of National Education [13] (Establishment of Teacher Certification Consortium), [12] (Certification for Teachers in Position) and Determination of Universities Organizing Teacher Certification in Position, (Mendiknas Decision).

Based on this opinion, it can be concluded that teacher certification is a very important part of policy in improving the quality of teacher work to realize national education goals, for the sake of the future as an answer in the era of globalization as it is today, besides it is expected that certification can bring a big influence for teachers who have been certified coupled with increased welfare, so as to be the driver of teacher certification to improve its performance.

Motivation is the process of producing the best product as a process. We cannot observe motivation directly, but we can deduce it from actions and verbalization, [15] "Motivation is a process rather than a product, as a process. We do not observe motivation directly but rather we infer it from action and verbalization".

Motivation as a person's relationship with the circumstances he/she faces because of the desire or need for the object from outside one's self, as an excuse to act in order to meet his life needs.[14] According to "Motivation can be defined as getting results through people or getting the best out of people". Motivation is defined as the best result obtained by a person or as a result obtained. Motivation is the desire to strive as hard as possible to achieve organizational goals, influenced by the ability to satisfy some individual needs

Work motivation as "something that gives rise to passion or encouragement of work.[16] Therefore, work motivation in work psychology is commonly called encouragement of work spirit.
Strong and weak labor motivation of a workforce also determines the size of his achievements. Work motivation can be concluded as a need that encourages a person to do deeds towards an objective to do an act in which the business is energized, directed, and sustainable towards achieving a goal based on a sense of responsibility, so that one becomes more disciplined in carrying out his work, as a process that causes intensity, direction, and continuous effort (persistence) of the individual towards achieving performance progress, as a driving factor of a person's behavior based on responsibility, as a result of psychological processes that reflect the interaction between attitudes and actions, thus producing the best products.

\section{METHODS}

This research was carried out at the Lempuing Subdistrict KKG of Ogan Komering Ilir Regency consisting of 10 State Elementary Schools. The time of this research was planned for 1 (one) semester, that are August to December 2020, this research used quantitative approach, namely descriptive quantitative research that means obtaining data in the form of numbers or quantitative data that is estimated [15] Research conducted by correlational associative using two independent variables namely certification $\left(\mathrm{X}_{1}\right)$ and work motivation $\left(\mathrm{X}_{2}\right)$ and one dependent variable namely teacher performance $(\mathrm{Y})$.

Population according to Arikunto that population is the total number of research subjects Subjects that have certain qualities and characteristics set by researchers to be studied and then drawn conclusions, where the population as a generalization area consisting of objects, [16] Population according to Arikunto that population is the total number of research subjects Subjects that have certain qualities and characteristics set by researchers to be studied and then drawn conclusions, where the population as a generalization area consisting of objects, [17] Samples are part or representative of the population studied. That is, if we intend to generalize the results of sample research, then it is called sample research. Generalizing what is meant is the conclusion raised in the research as a prevailing for the population.

All state elementary school teachers in The Lempuing SubDistrict KKG, Ogan Komering Ilir, who have been certified, are 65 teachers from 10 public elementary schools in lempuing sub-district $\mathrm{KKG}$ as a population in this study. 
This study used sampling techniques by total sampling, where the number of samples is equal to the number of existing populations. So that all teachers who have been certified in the KKG Lempuing District Ogan Komering Ilir as a sample of research.

Table. 1 Population and research samples

\begin{tabular}{llcc}
\hline No. & Name of School & Population & Samples \\
\hline 1. & SD Negeri 1 TM & 7 & 7 \\
2. & SD Negeri 2 TM & 11 & 11 \\
3. & SD Negeri 3 TM & 6 & 6 \\
4. & SD Negeri 4 TM & 5 & 5 \\
5. & SD Negeri 5 TM & 7 & 7 \\
6. & SD Negeri 1 TLH & 3 & 3 \\
7. & SD Negeri 1 TA & 8 & 8 \\
8. & SD Negeri 2 TA & 3 & 3 \\
9. & SD Negeri 1 TJ & 10 & 10 \\
10. & SD Negeri 2 TJ & 5 & 5 \\
& & & \\
& & & \\
\end{tabular}

(Source: processed data, 2020)

The technique used in the research is how to collect data, by using documentation and questionnaire

\section{RESULTS AND DISCUSSION}

\section{The Effect of Certification $\left(X_{1}\right)$ on Teacher Performance}

Based on the hypothetical test results obtained probability value $(0.000)$ less than the value of $\alpha$ $(0.05)$, in addition, for the value of thitung $(6,051)$ greaterttabel $(1,669)$, so it can be concluded that Ha is accepted, meaning there is a certification effect on teacher performance in the KKG Lempuing District Ogan Komering Ilir. The effect of certification on teacher performance of $36.8 \%$ of the remaining $63.2 \%$ was influenced by other factors that were not variables.

Based on the description above, it could be concluded that after the teacher is certified, the better the performance of teachers in the $\mathrm{KkG}$ Lempuing District Ogan Komering Ilir, and vice versa if the teacher is not certified, then the teacher performance was low or not maximum in the KKG Lempuing District Ogan Komering Ilir.

\section{The Effect of Work Motivation $\left(\mathrm{X}_{2}\right)$ on Teacher Performance}

Based on the hypothetical test results obtained a probability value $(0.000)$ less than the value of $\alpha$ (0.05), in addition, for the value of thitung $(5,861)$ greater ttabel $(1,669)$ so that it this means there is an influence of Work Motivation on Teacher Performance in kkg Lempuing District Ogan Komering Ilir. The effect of work motivation on teacher performance of $34.3 \%$ of the remaining $65.7 \%$ was influenced by other factors that were not variables in this study. The results of this study showed that the H02 Hypothesis was rejected and the $\mathrm{Ha} 2$ Hypothesis was accepted meaning that there was a positive and significant influence on the performance of teachers in the $\mathrm{KkG}$ of Lempuing District, Ogan Komering Ilir Regency on partial work motivation variables.

Based on the description above, it could be concluded that if the work motivation could be improved, then the teacher's performance was getting better and improved, and vice versa if the work motivation decreases, then the performance of teachers in the KKG Lempuing District Ogan Komering Ilir would decrease.

\section{The effect of certification $\left(X_{1}\right)$, work motivation $\left(\mathbf{X}_{2}\right)$ on teacher performance}

Based on the hypothetical test results obtained Fhitung value of 14,138 greater than $\mathrm{F}(0.05)$, then to determine the amount of Ftabel value can use Table $\mathrm{F}$ with the formula as follows. Ftabel $=\mathrm{F}[(1-\alpha)$ (numerator $\mathrm{dk}=\mathrm{k}),(\mathrm{dk}$ denominator $=\mathrm{n}-\mathrm{k}-1)] \mathrm{F}[(1-$ $0.05)$ (numerator $\mathrm{dk}=2),(\mathrm{dk}$ denominator $=65-2-1)]$ $\mathrm{F}[(1-0.05)(2)(62)]=3,150$, in addition to the probability value $(0.000)$ less than the value $\alpha(0.05)$, the Fbel value is 3.150 . Thus the value of Fhitung $(19,019)$ is greater than the value of Ftabel $(3,150)$ so that it could be concluded that $\mathrm{Ha}$ is accepted. As for the effect of certification and work motivation with a value of $38 \%$ jointly on the performance of teachers in the KkG Lempuing District Ogan Komering Ilir, the remaining $62 \%$ was influenced by other factors that were not intended variables in this study.

Based on the description above, it could be concluded that the factors that affect teacher performance are certainly very much, including 
certification and work motivation. Teacher performance is basically the result of interaction between these factors, where the results of this study showed that certification and work motivation contributed a very effective $38 \%$ to teacher performance. So there is a mutual influence between certification and work motivation on teacher performance. Work motivation would increase with the awareness of teachers who have been certified, this would make the teacher's performance better in the KKG Lempuing District Ogan Komering Ilir.

\section{CONCLUSION}

Based on the results of the study that certification and work motivation have a partial relationship to the improvement of teacher performance in the KKG Lempuing District Ogan Komering ilir, this means that teacher performance is determined by certification that basically lies in the ability of teachers professionally, with high work motivation owned, then the teacher would give the best to his students. And simultaneously have a significant effect on improving teacher performance in the KKG Lempuing District Ogan Komering ilir, this means that the performance of teachers to be achieved is influenced by certification as a label of teachers who have professional and work motivation, through certification owned as a form of recognition of professional teachers are able to encourage and change teacher understanding, it would increase work motivation then achieved good teacher performance as well.

\section{REFERENCES}

[1] Kristiawan, M., \& Rahmat, N. (2018). Peningkatan Profesionalisme Guru Melalui Inovasi Pembelajaran. Jurnal Iqra': Kajian Ilmu Pendidikan, 3(2), 373-390.

[2] Peraturan Pemerintah nomor 74 Tahun 2008 tentang Guru

[3] PERMENDIKNAS Nomor 16 Tahun 2005 tentang Standar Kualifikasi dan Kompetensi Pendidik.

[4] Peraturan Pemerintah nomor 19 Tahun 2005 tentang Standar Nasional

[5] Ballangan, F. M., \& Limbong, M. (2021). Pengaruh Peran Guru dan Media Pembelajaran Terhadap Motivasi Berprestasi Siswa Jurusan Teknik Kendaraan Ringan SMK Negeri 4 Tana Toraja. Attractive: Innovative Education Journal, 3(1), 32-51.
[6] Undang-Undang Republik Indonesia No 14 Tahun 2005 Guru dan Dosen.

[7] Yamin, Martinis.(2006). Sertifikasi profesi Keguruan di Indonesia. Cetakan ke 1. Gaung Persada Pers, Jakarta

[8] Notoatmojo, Soekidjo, (2009). Pengembangan Sumber Daya Manusia. Cetakan ke 4 Rineka Cipta, Jakarta.

[9] Fuad, M., Subandi, S., \& Muslan, G. (2021). Teachers' Professionalism and Parents' Motivation in Learning Aswaja at Ma Tri Bhakti At-Taqwa Raman Utara. Bulletin of Pedagogical Research, 1(1), 1-15.

[10] Supardi, (2014). Kinerja Guru. Rajawali Pers, Jakarta.

[11] Renata. (2018). Pengaruh Supervisi Kepala Sekolah dan Motivasi Berprestasi terhadap Efektivitas Guru SMP Negeri di kota Palembang Tesis Universitas PGRI Palembang.

[12] Undang-Undang RI Nomor 20 Tahun 2003 tentang Sistem Pendidikan Nasional.

[13] Payong R, Marselus.(2011). Sertifikasi Profesi Guru (Konsep Dasar, Problematika, dan Implementasinya). PT. Indeks Permata Puri Media, Jakarta.

[14] Fuad, M., Subandi, S., \& Muslan, G. (2021). Teachers' Professionalism and Parents' Motivation in Learning Aswaja at Ma Tri Bhakti At

[15] Mastufah, M. (2019). Peningkatan Motivasi Hasil Belajar Ekonomi Melalui Model Pembelajaran Student Centered Learning. Attractive: Innovative Education Journal, 1(1), 40-52.-Taqwa Raman Utara. Bulletin of Pedagogical Research, 1(1), 1-15.

[16] Keputusan Mendiknas No. 056/P/2007 tentang Pembentukan Konsorsium Sertifikasi Guru

[17] Anoraga, Panji. (2014). Psikologi Kerja. Cetakan 6. Rineka Cipta, Jakarta.

[18] Sugiyono, (2012). Metode Penelitian Pendidikan; pendekatan kuantitatif, kualitatif, dan R\&D. Alfabeta. Bandung. 